\title{
Laryngeal Granuloma
}

National Cancer Institute

\section{Source}

National Cancer Institute. Laryngeal Granuloma. NCI Thesaurus. Code C3068.

An inflammatory lesion of the vocal cords. 